\title{
Comparative Evaluation of Cell Block Method and Smear Cytology in Fine Needle Aspiration Cytology of Intra-abdominal Mass Lesions
}

\author{
Sourav Bhowmik ${ }^{1}$, Indranil Chakrabarti ${ }^{*}$, Piyali Ghosh ${ }^{3}$, Pranati Bera ${ }^{2}$, Tarak Banik ${ }^{4}$ \\ 1. Dept. of Pathology, Ruby General Hospital, Kolkata, India \\ 2. Dept of Pathology, North Bengal Medical College, The West Bengal University Of Health \\ Sciences, Siliguri, Darjeeling, India \\ 3. Dept of Pathology, Calcutta National Medical College, The West Bengal University Of \\ Health Sciences, Kolkata, India \\ 4. Dept of Pathology, Malda Medical College, The West Bengal University Of Health Sciences, \\ Malda, India
}

\begin{tabular}{c}
\hline KEYWORDS \\
\hline Fine Needle Aspiration \\
Cytology; \\
Cell Block \\
\end{tabular}

\section{Article Info}

Received 29 Oct 2016; Accepted 05 April 2018; Published Online 17 July 2018;

\section{ABSTRACT}

Background \& objective: Fine needle aspiration cytology (FNAC) is an easy, rapid, and less hazardous tool to diagnose the intra-abdominal lesions with various imaging modalities adding to its sensitivity and accuracy. However, sometimes it does not yield adequate information for precise diagnosis and the risk of false-negative and indeterminate diagnosis is always present. Cellblock preparations may be particularly helpful in such problematic cases.

The current study aimed atevaluating and comparing the cytological as well as histopathological features of different intra-abdominal mass lesions.

Methods: Image-guided FNAC followed by cell block were performed on 167 patients from June 2012 to May 2013. Histologically correlated 111 cases were evaluated. Results of conventional smear, cell block, and combination of FNAC with cell block were compared with histopathological findings regarding diagnostic sensitivity, specificity, and accuracy of diagnosis.

Results: Cell block was more specific to diagnose these lesions than FNAC $(95.49 \%$ versus $90.09 \%$ ). Combined application of cell block with FNAC was more specific (96.39\%) than cell block alone with 100\% diagnostic accuracy.

Conclusion: Application of a combination of cell block with FNAC was more useful to diagnose intra-abdominal mass lesions.

Dr. Indranil Chakrabarti, Dept. of Pathology, North Bengal Medical College, Sushrutanagar, Darjeeling, West Bengal, India. E-mail: drinch@rediffmail.com.

Corresponding information: Copyright (C) 2018, IRANIAN JOURNAL OF PATHOLOGY. This is an open-access article distributed under the terms of the Creative Commons Attribution-non-
commercial 4.0 International License which permits copy and redistribute the material just in noncommercial usages, provided the original work is properly cited.

\section{Introduction}

Intra-abdominal masses have always been an enigma in surgical practice with significant diagnostic difficulties. Fine needle aspiration cytology (FNAC) can play a useful role due to its rapid, less hazardous, and easy to perform diagnostic modality. In a majority of cases, diagnosis obtained by FNAC can be a substitute for surgical procedures such as diagnostic laparotomy $(1,2)$.Various imaging techniques such as ultrasonography (USG), computed tomography (CT), or fluoroscopy can be used as a guide for FNAC by adding to the yield of the aspirate and providing important diagnostic clues. However, according to Zito et al., (3) FNAC sometimes does not yield information for precise diagnosis and there is always the risk of false-negative diagnosis and indeterminate diagnosis. In these cases, cell block preparations may be helpful. It can be particularly useful to categorize tumors that may not be possible from smears themselves. The technique of cell block is simple and reproducible and uses routine safe laboratory chemicals and techniques. The aspirated material remaining after cytological preparations may be used for cell blocks. The benefit of cell block technique is the recognition of histologic pattern of tissue as well 
as biopsy that usually cannot be reliably identified in smears (4). The cell block sections are also suited for a wide variety of histochemical stains and immunocytochemistry (5). Richardson et al.,showed that additional diagnosis of cancer can be rendered in $5 \%$ of fluid specimens if smear technique is supplemented by cell block sections of residual material (4).

Thus, the current study aimed at evaluating and comparing the cytological as well as cellblock histopathological features of different intra-abdominal mass lesions.

\section{Materials and Methods}

The current study was conducted in the Department of Pathology, in association with the Department of Radio diagnosis in a rural, tertiary care hospital covering a period of 12 months, from June 2012 to May 2013, over all the patients presenting with intra-abdominal mass lesions after taking the approval from Institutional Ethical Committee. After thorough examination of patients, including relevant clinical history and examination, FNAC was conducted under ultrasound and CT guidance (whichever applicable). Aspiration was performed in each case using a 22-gauge needle attached to a $10-\mathrm{mL}$ syringe for superficial masses and a 22-gauge spinal needle for deep seated masses. Air dried and alcohol fixed smears were prepared from the collected materials and stained with Leishman-Giemsa and Hematoxylin and Eosin (H\&E) stains, respectively. Ziehl-Neelsen (Z-N) stain was performed whenever caseous material or pus was aspirated to exclude tuberculosis. The remaining material in the aspirating syringe and needle hub were collected and preserved in 10\% normal buffer formalin for cell block preparation overnight. The preserved tissue material was centrifuged at 2500 rpm for 10 minutes and the formed cell button was treated with fresh plasma and thrombin to form clot. The clotted cell button was then processed as routine biopsy specimen and stained with H\&E. Among the results of FNAC and cell block, cell block diagnosis was given priority. Results of conventional smear, cell block, and combination of FNAC with cell block were compared with the available histopathological diagnosis regarding diagnostic sensitivity, specificity, and accuracy of diagnosis.

\section{Results}

A total of 167 patients were studied. Most of the patients presented with abdominal mass or pain in the abdomen, and clinical examination revealed intra-abdominal mass lesions. After radiological evaluation, all the patients were subjected to fine needle aspiration of their masses under ultrasound or computed tomography (CT) guidance. In 150 cases, yield was satisfactory for reporting. Out of the remaining 17 cases repeat aspiration yielded satisfactory material in 11 cases; therefore, all together 161 cases were included in the study.

Out of 161 patients, $74(45.96 \%)$ were male and 87 $(54.03 \%)$ female. The youngest patient was a 2-yearold male presenting with hepatoblastoma and the oldest was an 85-year-old male presenting with nonHodgkin lymphoma in the retroperitoneum. The majority of patients were within the age range of 31 to 60 year (114 cases, $70.80 \%$ ) with a peak in the 5 th decade $(31.92 \%)$ and a median age of 48 years. Malignant lesions were more common (124 cases, $77.01 \%$ ) than the non-neoplastic lesions (21.11\%) and benign tumors $(1.86 \%)$.

Among the 34 non-neoplastic lesions, the majority were of tubercular lymphadenopathy (Figure 1A,B) (15 cases, 44.12\%) along with one case of tubercular salpingitis. AFB could be demonstrated in 12 of them by Z-N stain. In addition, some cases of benign cystic lesions including hydatid cyst in liver (Figure 1C,D) and polycystic kidney, suppurative lesions, and pyonephrosis were also found (Table 1).

Among the three cases of benign neoplasms in the current study, the majority (66.67\%) wasof soft tissue origin and only one case (33.34\%) of mucinous cystadenoma of ovary was observed. The benign neoplasms of soft tissue origin were diagnosed as neurofibroma; both by FNAC and cell block and one of them could be followed up and confirmed by histopathology (Table 2). 
181. Comparative Evaluation of Cell Block ...

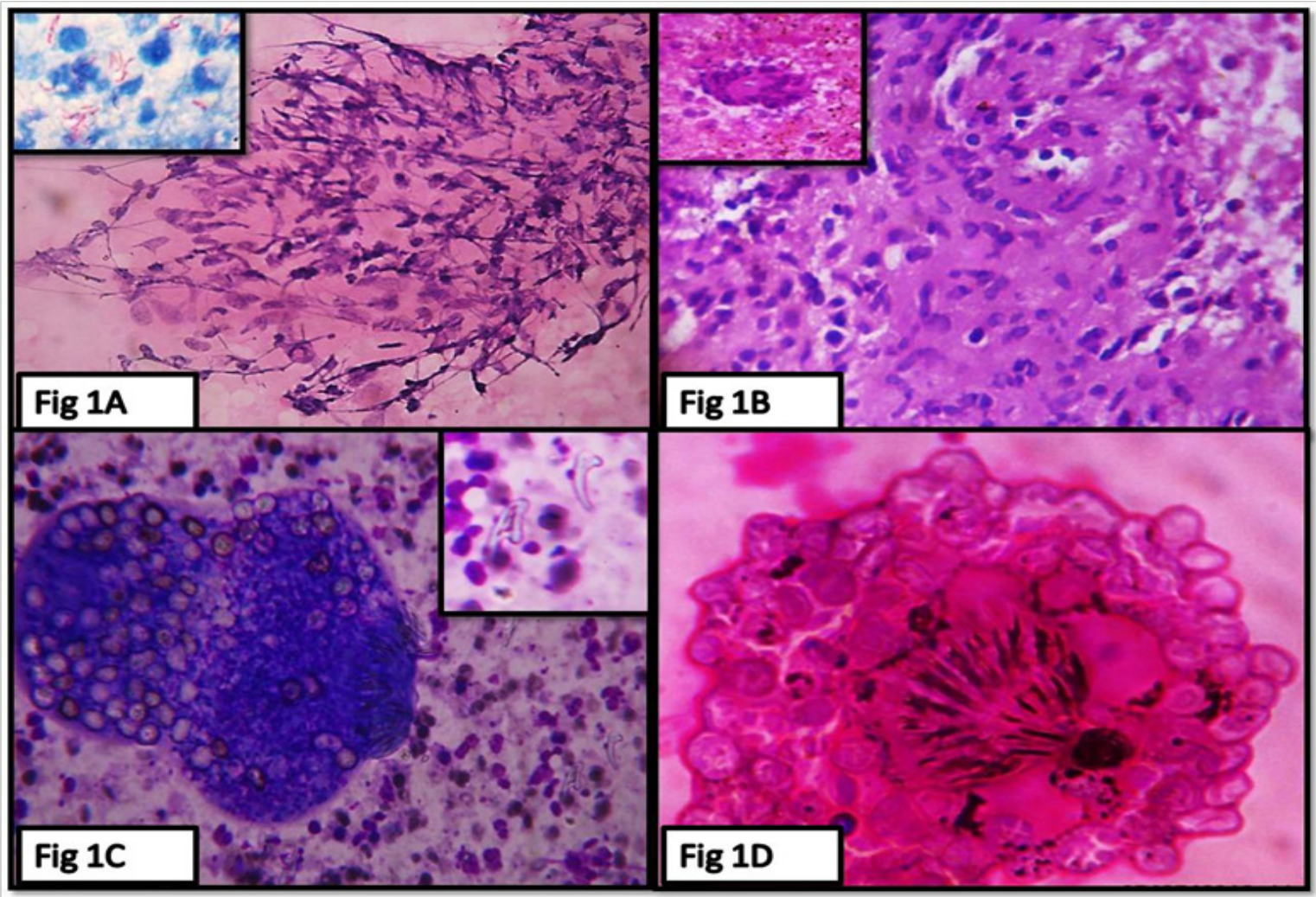

Figure1. Microphotograph showing (A) Aspirate of epithelioid cell granuloma in tubercular lymphadenitis (L-Gstain,400X);inset showing numerous AFB (Z-N stain,1000X); (B) Epithelioid cell granuloma in cell block (H \& E stain,400 X);inset showing giant cell; (C)Hydatid cyst (L-G stain,400X);inset showing hooklets; (D) Hydatid cyst (H \& E stain,400 X)

Table 1. Distribution of Non-neoplastic Intra-abdominal Mass Lesions

\begin{tabular}{|c|c|c|c|c|c|}
\hline Organ & Lesions & $\mathbf{N}$ & $\%$ & $\mathbf{N}$ & $\%$ \\
\hline \multirow{3}{*}{ Liver } & Liver abscess & 4 & 11.76 & 10 & 29.41 \\
\hline & Regenerative nodule & 4 & 11.76 & & \\
\hline & Hydatid cyst & 2 & 5.88 & & \\
\hline Pancreas & Benign cystic lesion & 1 & 2.94 & 1 & 2.94 \\
\hline \multirow{2}{*}{ Kidney } & Polycystic kidney & 1 & 2.94 & 2 & 5.88 \\
\hline & Pyonephrosis & 1 & 2.94 & & \\
\hline Tube and ovary & Tubercular salpingitis & 1 & 2.94 & 1 & 2.94 \\
\hline \multirow{2}{*}{ Lymph node } & Tubercular lymphadenitis & 15 & 44.12 & 18 & 52.94 \\
\hline & Reactive hyperplasia of lymph node & 3 & 8.82 & & \\
\hline \multirow{2}{*}{ Others } & Psoas abscess & 1 & 2.94 & 2 & 5.88 \\
\hline & Inflammatory lesion & 1 & 2.94 & & \\
\hline
\end{tabular}

Table 2. Distribution of Benign Intra-abdominal Mass Lesions

\begin{tabular}{cccccc}
\hline Organ & Lesion & N & \% & N & \% \\
\hline Ovary & Mucinous cystadenoma & 1 & 33.33 & 1 & 33.33 \\
Soft tissue & Neurofibroma & 2 & 66.67 & 2 & 66.67 \\
\hline
\end{tabular}


Of the 124 malignant lesions, 77 (62.09\%) were of hepatic origin followed by 16 (12.90\%) of gall bladder, $11(8.87 \%)$ of lymph node, six $(4.83 \%)$ of ovary, three $(2.42 \%)$ each of renal, intestinal, pancreatic and soft tissue origin, and two cases (1.61\%) arising from adrenal gland were found (Table 3).

Table 3. Distribution of Malignant Intra-abdominal Mass Lesions

\begin{tabular}{|c|c|c|c|c|c|}
\hline Organ & Lesion & $\mathbf{N}$ & $\%$ & $\mathbf{N}$ & $\%$ \\
\hline \multirow{7}{*}{ Liver } & Metastatic adenocarcinoma & 45 & 36.29 & 77 & 62.09 \\
\hline & Hepatocellular carcinoma & 26 & 20.97 & & \\
\hline & Metastatic squamous cell carcinoma & 2 & 1.61 & & \\
\hline & Hepatoblastoma & 1 & 0.81 & & \\
\hline & Metastatic small cell carcinoma & 1 & 0.81 & & \\
\hline & Metastatic large cell neuroendocrine carcinoma & 1 & 0.81 & & \\
\hline & Metastatic papillary adenocarcinoma & 1 & 0.81 & & \\
\hline \multirow{2}{*}{ Gallbladder } & Adenocarcinoma & 14 & 11.29 & 16 & 12.90 \\
\hline & Adenosquamous carcinoma & 2 & 1.61 & & \\
\hline \multirow{4}{*}{ Lymph node } & Non-Hodgkin lymphoma & 5 & 4.03 & 11 & 8.87 \\
\hline & Metastatic adenocarcinoma & 4 & 3.23 & & \\
\hline & Burkitt lymphoma & 1 & 0.81 & & \\
\hline & Hodgkin lymphoma & 1 & 0.81 & & \\
\hline \multirow{2}{*}{ Ovary } & Serous cystadenocarcinoma & 5 & 4.03 & 6 & 4.84 \\
\hline & Dysgerminoma & 1 & 0.81 & & \\
\hline \multirow{3}{*}{ Kidney } & Wilmstumor & 1 & 0.81 & 3 & 2.41 \\
\hline & Renal cell carcinoma,-clear cell variety & 1 & 0.81 & & \\
\hline & RCC, chromophobe variety & 1 & 0.81 & & \\
\hline \multirow{3}{*}{ Pancreas } & Ductal adenocarcinoma & 1 & 0.81 & 3 & 2.41 \\
\hline & Mucinous adenocarcinoma & 1 & 0.81 & & \\
\hline & Papillary adenocarcinoma & 1 & 0.81 & & \\
\hline Intestine & Adenocarcinoma & 3 & 2.42 & 3 & 2.41 \\
\hline Adrenal & Adrenocortical carcinoma & 2 & 1.61 & 2 & 1.61 \\
\hline \multirow{2}{*}{ Soft tissue } & Pleomorphic sarcoma & 2 & 1.61 & 3 & 2.41 \\
\hline & MPNST & 1 & 0.81 & & \\
\hline
\end{tabular}

RCC, renal cell carcinoma; MPNST, malignant peripheral nerve sheath tumor

In the liver, metastatic deposit of adenocarcinoma was the most commonly observed malignancy $(n=45$, $58.44 \%$ ) followed by hepatocellular carcinoma $(n=26,33.77 \%)$ and one case of hepatoblastoma in a two-year-old male. There were also two cases of secondary deposit of squamous cell carcinoma in liver along with cases of deposit of small cell carcinoma of lung, large cell neuroendocrine carcinoma, and papil- lary adenocarcinoma in the current study. In two cases of hepatocellular carcinoma, FNAC failed to produce conclusive diagnosis and a cytological diagnosis of poorly differentiated carcinoma was rendered. But in these cases, cell block helped to reach the definite diagnosis, which also corroborated with the histopathological diagnosis later on. However, in one case of metastatic deposit of adenocarcinoma in liver, cell 
block could not give conclusive impression due to low diagnostic yield. In this case, the FNAC was conclusive, which corroborated with the histopathological diagnosis (Figure 2 A-D).

Among the lesions of gall bladder, 14 cases (87.5\%) of adenocarcinoma along with two cases $(12.5 \%)$ of adenosquamous carcinoma were observed in the current study, cytologically.

The most common malignancy observed in the lymph node was non-Hodgkin lymphoma $(n=5$, $45.45 \%$ ) followed by metastatic deposit of adenocarcinoma $(n=4,36.36 \%)$. There were also cases of Hodgkin lymphoma and the Burkitt lymphoma in a four-year-old seropositive female in the current study.
Five cases $(83.33 \%)$ of serous cystadenocarcinoma along with one case of dysgerminoma were observed among the ovarian malignant lesions. Of the renal lesions cases of the Wilms tumor (Figure 3A,B), clear cell carcinoma, and chromophobe renal cell carcinoma were diagnosed by FNAC and cell block and supported by histopathology. Cases of ductal adenocarcinoma, mucinous adenocarcinoma, and papillary adenocarcinoma were found and histopathology revealed that the cases were of pancreatic origin.

Two interesting cases of adrenocortical carcinoma were also found in the current study, which were later confirmed by histopathology.

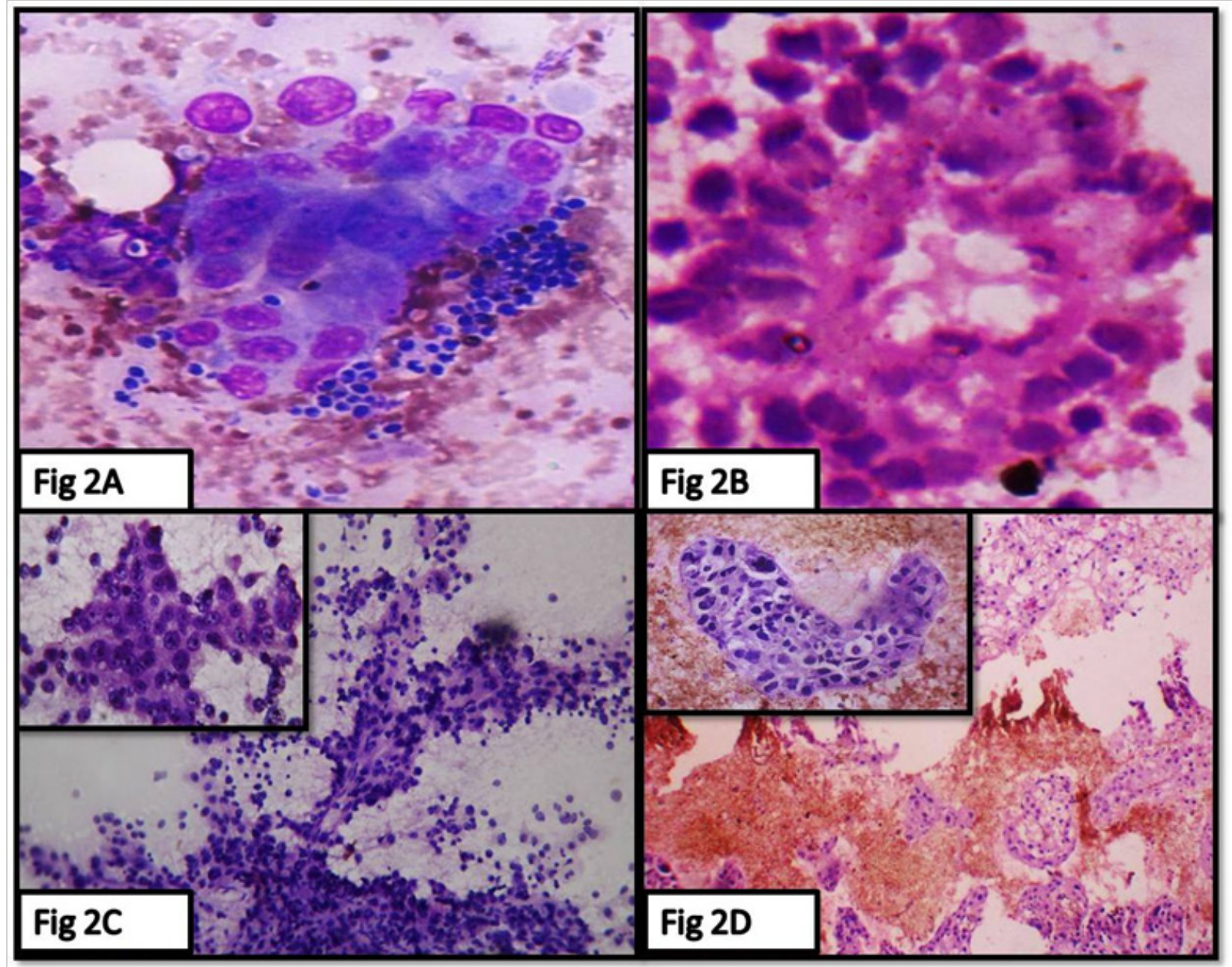

Figure 2. Microphotograph showing (A) Aspirate of metastatic adenocarcinoma in liver (L-G stain, 400X); (B) Cell block showing well-defined malignant glands (H \& E stain, $400 \mathrm{X})$; (C)Aspirate from hepatocellular carcinoma (L-G stain, 400X);inset showing a closer view of malignant hepatocytes; (D) Cell block of the same case as (C) showing well defined trabecular arrangement of malignant hepatocytes (H \& E stain, $400 \mathrm{X})$;inset showing a closer view of the same (H \& E stain, 400X). 


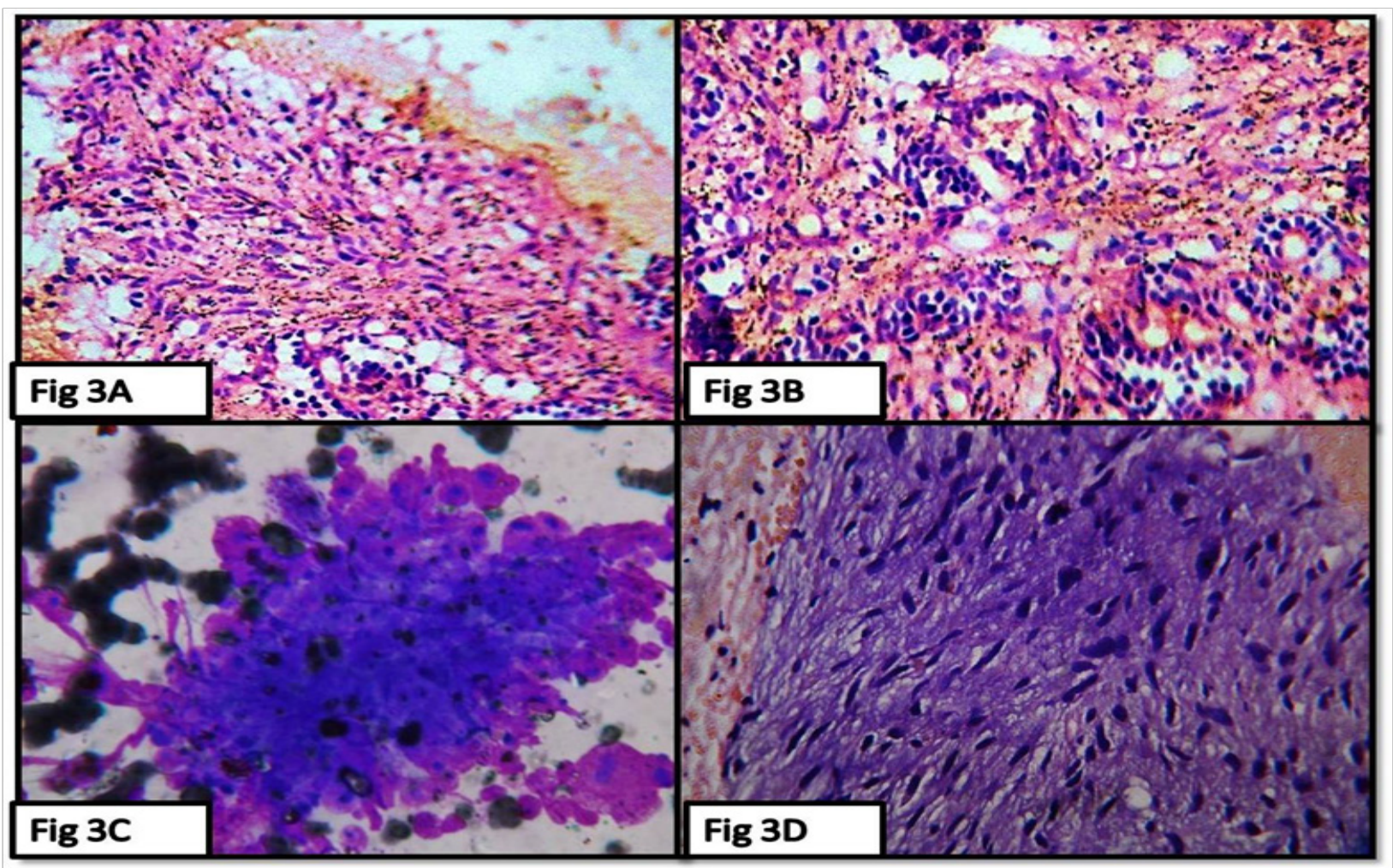

Figure 3. (A) Cell block preparation of a case of the Wilms tumor highlighting spindle cell component(H \& E stain, 100X); (B) Tubular structures of the same case as (A)(H \& E stain, 100X); (C) Aspirate showing pleomorphic sarcoma (L-G stain, 400X); (D) Cell block of the same case as (C) showing features suggestive of leiomyosarcoma (H \& E stain; 400X)

One interesting case of retroperitoneal mass in a 75-year-old male was found in the current study, which was identified to be arising from inferior vena cava on magnetic resonance imaging (MRI). On FNAC, it was diagnosed as pleomorphic sarcoma (Figure 3C). But, on cell block and subsequent histopathology it could be diagnosed as leiomyosarcoma (Figure 3D) arising from inferior vena cava. It was later confirmed by immunohistochemistry. Among the other soft tissue lesions, cases of pleomorphic sarcoma and malignant spindle cell lesion were rendered cytologically. One of them could be specifically categorized as malignant peripheral nerve sheath tumor (MPNST) by cell block and also corroborated with histopathology. The other one could not be specifically diagnosed either by cell block or FNAC, which later on came out as malignant fibrous histiocytoma on histopathology.

Histopathological correlation could be done on 111 cases out of the 161. Although cell block as well as FNAC could diagnose all the neoplastic malignant lesions as malignant with $100 \%$ sensitivity, in two cases of hepatic neoplasms, two cases of gall bladder carcinoma, and one case of lymphoid neoplasm specific cytopathological diagnoses were inconsistent. Two cases of metastatic deposit of adenocarcinoma diagnosed in cell block as well as FNAC came out as poorly differentiated hepatocellular carcinoma in histopathology. One case of adenosquamous carcinoma of gall bladder was misinterpreted as adenocarcinoma cytologically, but could be correctly identified in cell block preparation supported by histopathology. However, another case of adenosquamous carcinoma was falsely identified as adenocarcinoma in both cell block and FNAC, probably due to selective sampling. Among the lymphoid neoplasms, one case of metastatic deposit of poorly differentiated adenocarcinoma was wrongly interpreted as non-Hodgkin lymphoma by FNAC. But in this case, cell block could render the correct diagnosis corroborated with the histopathological diagnosis (Table 4). 
185. Comparative Evaluation of Cell Block ...

Table 4. Discordant Cases of FNAC and Cell Block WithHistopathologicalDiagnoses

\begin{tabular}{|c|c|c|c|c|c|}
\hline Organ & FNAC Diagnosis & $\begin{array}{c}\text { Cell Block Diag- } \\
\text { nosis }\end{array}$ & HP Diagnosis & $\begin{array}{c}\text { No.of Discor- } \\
\text { dant Cases in } \\
\text { FNAC }\end{array}$ & $\begin{array}{c}\text { No.of Discor- } \\
\text { dant Cases in } \\
\text { Cell Block }\end{array}$ \\
\hline \multirow{2}{*}{ Liver } & $\begin{array}{l}\text { Poorly differentiated ade- } \\
\text { nocarcinoma }\end{array}$ & $\mathrm{HCC}$ & $\mathrm{HCC}$ & 2 & - \\
\hline & Metastatic adenocarcinoma & $\begin{array}{l}\text { Metastatic adenocar- } \\
\text { cinoma }\end{array}$ & $\mathrm{HCC}$ & 2 & 2 \\
\hline \multirow{2}{*}{ Gallbladder } & Adenocarcinoma & $\begin{array}{l}\text { Adenosquamous } \\
\text { carcinoma }\end{array}$ & $\begin{array}{l}\text { Adenosquamous } \\
\text { carcinoma }\end{array}$ & 1 & - \\
\hline & Adenocarcinoma & Adenocarcinoma & $\begin{array}{l}\text { Adenosquamous } \\
\text { carcinoma }\end{array}$ & 1 & 1 \\
\hline Lymph node & NHL & $\begin{array}{l}\text { Metastatic adenocar- } \\
\text { cinoma }\end{array}$ & $\begin{array}{l}\text { Metastatic adenocar- } \\
\text { cinoma }\end{array}$ & 1 & - \\
\hline \multirow[b]{2}{*}{ Soft tissue } & Pleomorphic sarcoma & Leiomyosarcoma & Leiomyosarcoma & 1 & \\
\hline & Pleomorphic sarcoma & $\begin{array}{l}\text { Pleomorphic sar- } \\
\text { coma }\end{array}$ & MFH & 1 & 1 \\
\hline Total & & & & $9 / 111$ & $4 / 111$ \\
\hline
\end{tabular}

FNAC, fine needle aspiration cytology; HP, ;Histopathology, HCC, hepatocellular carcinoma; NHL, non-Hodgkin lymphoma; MFH, malignant fibrous histiocytoma

Thus, FNAC could specifically diagnose $89.89 \%$ of malignant lesions, whereas cell block could render correct diagnosis with a specificity of $95.95 \%$. The current study also revealed that if both FNAC and cell block were used as complimentary to each other malignant lesions could be diagnosed with a specificity of $97.95 \%$.Overall, cell block had a sensitivity and specificity of $100 \%$ and $95.49 \%$ respectively, which was clearly better than the conventional smear cytology (100\% and $90.09 \%)$. Combination of cell block and FNAC attained sensitivity and specificity of $100 \%$ and $96.39 \%$, respectively.

\section{Discussion}

FNAC is now a well-established, simple, safe, and reliable diagnostic modality. It is used as the first line of investigation of lesions in different organs and sites. Image-guided FNAC with the help of fluoroscopy, high resolution CT, USG, and the recent MRI play an immensely beneficial role in the diagnosis of deep seated lesions (6). However, diagnostic failure rate of FNAC can be as high as $45 \%$ (7). An inconclusive diagnosis on FNAC may be due to various causes such as poor spreading, air drying artefact and presence of thick tissue fragments despite aspiration of adequate material (8-10). Under such circumstances, cell block may play a very crucial role as diagnostic modality, which combines the advantages of both cytology and histology. Different methods of cell block preparation are reported by various authors $(5,11)$, all of which added to the armamentarium of aspiration cytology.

In the current study, comparative evaluation of cell block over conventional smear cytology was assessed over 167 cases of intra-abdominal mass lesions. In the current study, the age of the patients ranged 2-85 years, with male: female ratio of $1: 1.17 ; 31.92 \%$ of cases were in their 5th decade of age, which can be compared with the findings of GovindKrishna et al. (22.2\%) (12).

The current study showed that the maximum number of cases were of hepatic origin (62.09\%) followed by gallbladder $(12.90 \%)$ and lymph node $(8.87 \%)$. The least number of cases arose from adrenal gland (1.61\%). This kind of distribution of cases was also comparable to the studies by Pachori (13). Steward et al., also found maximum cases arising from liver $(81.5 \%)$ followed by pancreas (12\%) (14). However, the findings of Govind Krishnan et al., differed from those of the current study in which retroperitoneum $(23.2 \%)$ was the commonest organ presenting intraabdominal mass lesions (12). 
Out of the 161 cases, malignant lesions were more common $(n=124,77.01 \%)$ than the non-neoplastic lesions $(21.11 \%)$ and benign tumors (1.86\%) in the current study. Malignant lesions were also predominant in the studies conducted by some other authors (12-14).

An overall improvement in final diagnosis was noted in the current study when conventional smear cytology was complimented with cell block technique, raising the sensitivity and specificity up to $100 \%$ and $96.39 \%$, respectively. Khan $\mathrm{N}$ et al., also found complimentary use of cell block and FNAC to be beneficial with a diagnostic accuracy of $85.3 \%$ (15). However, Wojcik and Selvaggi found that $84 \%$ of cases had identical information on both cell block and smear cytology (16). The current study findings werealso supported by KeyhaniRofaga et al., (17) who reporting that $55 \%$ of original smear diagnoses improved after cell block examination. Kern and Heber also got additional diagnostic information by the application of cell block in $60.3 \%$ of cases (18); thus, helping in the conclusive diagnosis. Sharma et al., (19) showed that cell blocks improved the efficacy of cytodiagnosis, particularly for malignant and suspicious cases. They also showed that immunomarkers could be reliably reported on cell blocks in $94.7 \%$ of the cases. Shivakumarswamy U et al., (20) in their study on pleural fluid cytology showed that cell block study was better than conventional smears alone and improved the diagnosis of malignancy by $15 \%$ even on fluid cytology.

\section{Conclusion}

The current study showed that the combined use of cell block and FNAC was more specific and sensitive to diagnose intra-abdominal mass lesions than the conventional smear cytology alone.

\section{Acknowledgements}

We are thankful to the staff and technichians of Department of Pathology, North Bengal Medical College, for their help and support

\section{Conflict of interests}

The authors declared no conflict of interest.

\section{References}

1. Aftab Khan A, Jan GM, Wani NA. Fine Needle Aspiration of Intra-abdominal masses for cytodiagnosis. J Indian Med Assoc. 1996;94(5):1679.

2. Nautiyal S, Mishra RK, Sharma SP. Routine and ultrasound guided FNAC of intra abdominal lumps - A comparative study. J Cytol. 2004;21(3):129-32.

3. Zito FA, Gadaleta CD, Salvatore C, Filotico R, Labriola A, Marzullo A et al. A modified cell block technique for fine needle aspiration cytology. ActaCytol. 1995;39(1):93-9. PMID: $\underline{7847016}$

4. 4. Bales Carol E. LaboratoryTechniques. In, Koss Leopold G. Koss' Diagnostic Cytology, 5nd ed. Philadelphia: Lippincott Williams \&Wilkins; 2006. p.1590.

5. 5. Nathan NA, Narayan E, Smith MM, Horn MJ. Improved Preparation and Its Efficacy in Diagnostic Cytology. Am J ClinPathol. 2000;114(4):599-606. https://doi.org/10.1309/ G035-P2MM-D1TM-T5QE_PMID: 11026107

6. Mondal A, Roy C K, Biswas J. Utility of imaging modalities in diagnostic FNAC. J Cytol. 2002;19(3):123-8.

7. Lee R, Foster RS, Papillo JL. Fine needle aspiration of the breast:importance of aspirator. Acta Cytol. 1987;31(3):281-4. PMID:3473861

8. 8. Sanchez N, Selvaghi SM. Utility of Cell Blocks in the diagnosis of thyroid Aspirates: Diagn. Cytopathol. 2006;34(2):89-92. https:// doi.org/10.1002/dc.20385 PMID:16514670

9. Svante R Orell. Manual and atlas of fine needle aspiration cytology. New York: Churchill Livingstone; 1992. p.96.

10. Chen PK. Artifacts of cytology cell block in fine needle aspiration biopsy of thyroid. Diagn Cytopathol. 2004;31(5):362-3. https://doi. org/10.1002/dc.20107 PMID:15468119

11. Leung SW, Bedard YC. Immunocytochemical staining on ThinPrep processed smears. Mod Pathol. 1996;9(3):304-6. PMID:ㅎ85232 
12. Govind Krishna SR, Ananthakrishanan N, Narasimhan R, Veliath AJ.Accuracy of Fine Needle Aspiration Cytology of Abdominal Masses without Radiological Guidance. Indian J Pathol Microbiol. 1993;36(4):442-52.

13. Pachori RM. Real time ultrasound guided aspiration biopsy of abdominal masses. An experience in a developing country. Indian J Radio Img. 1989;43:223-6.

14. Steward CJR, Coldeway J. Comparison of fine needle aspiration cytology and needle core biopsy in the diagnosis of radiologically detected abdominal lesions. J Clin Pathol. 2002;55(2):93-

7. https://doi.org/10.1136/jcp.55.2.93

15. Khan N, Sherwani RK, Afroz N, Kapoor S. Usefulness of cell block versus smears in malignant effusion cases. J Cytol. 2006;23(3):129-32.

16. Wojcik EM, Selvaggi SM. Comparison of smears and cell block in the fine needle as- piration Diagnosis of recurrent gynecologic malignancies. Acta Cytol. 1991:35(6):773-6. PMID: 1719722

17. Keyhani-Rofaga S, O'Toole RV, Leming MF. Role of cell block in fine needle aspiraton. Acta Cytol. 1984;28:630-1.

18. Kien WM, Haber H. Fine needle aspiration mini biopsies. ActaCytol 1986;30:403-8.

19. Sharma R, Nagaich N, Gupta S, Yashvardhan, Nepalia S. Role of Cell Block in DiagnosticsA New Paradigm in Cancer Diagnosis. Int Clin Pathol J. 2015;1(5):00025. https://doi. org/10.15406/icpj1.2015.01.00025

20. Shivakumarswamy U, Arakeri SU, Karigowdar MH, Yelikar B. Diagnostic utility of the cell block method versus the conventional smear study in pleural fluid cytology. J Cytol. 2012;29(1):115. PMID:22438610 PMCID:PMC3307444

\section{How to Cite This Article}

Bhowmik S, Chakrabarti I, Ghosh P, Bera P, Banik T. Comparative Evaluation of Cell Block Method and Smear Cytology in Fine Needle Aspiration Cytology of Intra-abdominal Mass Lesions. Iranian Journal of Pathology, 2018; 13(2): 179-187. 